\title{
LANDSCAPES AND HYDROLOGICAL REGIME LINKAGES: CASE STUDY OF CHANDIHOLÉ, AGHANASHINI
}

\author{
Vinay $\mathbf{S}^{1}$, Vishnu D $\mathbf{M}^{2}$, Srikanth $\mathbf{N}^{3}$, Subash Chandran $\mathrm{M} \mathrm{D}^{4}$, Bharath $\mathrm{S}^{5}$, Shashishankar $\mathrm{A}^{6}$, \\ Ramachandra $\mathbf{T} \mathbf{V}^{7}$ \\ ${ }^{I}$ Energy and Wetlands Research Group, Centre for Ecological Science, Indian Institute of Science, Bengaluru \& \\ Visvesvaraya Technological University, Belgaum \\ ${ }^{2}$ Energy and Wetlands Research Group, Centre for Ecological Science, Indian Institute of Science, Bengaluru \\ ${ }^{3}$ Energy and Wetlands Research Group, Centre for Ecological Science, Indian Institute of Science, Bengaluru \\ ${ }^{4}$ Energy and Wetlands Research Group, Centre for Ecological Science, Indian Institute of Science, Bengaluru \\ ${ }^{5}$ Energy and Wetlands Research Group, Centre for Ecological Science, Indian Institute of Science, Bengaluru \\ ${ }^{6}$ AMC college of Engineering, Bangalore \\ ${ }^{7}$ Energy and Wetlands Research Group, Centre for Ecological Science, Indian Institute of Science, Bengaluru
}

\begin{abstract}
Landscape is a mosaic of heterogeneous elements and the structure of a landscape decides the functional ability - hydrologic, bio-geo-chemical cycling, etc. The current study focusses on the landcover dynamics linkages with the hydrologic regime in Chandiholé sub-catchments of Aghnashini River. Various sub catchments are Yaana, Beilangi, Aanegundi(Chandiholé) and Masihalla. Land use in each sub-catchment was analysed using spatial data acquired through space borne Indian Remote Sensing sensors (IRS LISS4 FMX), through supervised classifier based on Gaussian Maximum likelihood algorithm. Land use analysis indicated that Yaana was dominated by evergreen forests (over 95\%), where as other sub-catchments had mixed landscapes. Hydrological yield is assessed based on monitoring stream discharges during May 2014 and April 2016 through area velocity method. Yaana stream is perennial (with 12 months of discharge) and yield varying between 1.3 to $97.4 \mathrm{~mm} /$ day followed by Aanegundi a mixed catchment fed by Yaana stream was intermittent (flow variability 10 - 12 month) across seasons has water yield of $0.07 \mathrm{~mm} /$ day to $82.39 \mathrm{~mm} /$ day, Mastihalla and Beilangi were also intermittent with 7 to 10 month of water yield. Yaana stream had higher base flow where as other catchments had higher overlandflows during monsoon. Despite lower rainfall during 2015, water discharges were observed during all 12 months in Yaana stream with the relatively higher water yield. The study confirms the linkages of hydrological and catchment vegetation cover (undisturbed forest patches in Yaana) in sustaining water while catering to the societal and environmental water requirements.
\end{abstract}

Keywords - Hydrological Regime, Land use, Stream Gauging, Water shed management

\section{INTRODUCTION}

Landscape is a collection of interacting dynamic elements. Landscape structure (size, shape and configuration) affects its functional aspects such as bio-geo chemical cycling and hydrologic regimes. The changes in landscapes can be either natural or anthropogenic, which affects the processes such as hydrology, ecology. Landscape heterogeneity governs spatiotemporal variability of hydrological states and fluxes, scale dependent flow and transport properties. Large scale changes in land use land cover (LULC) alter the spatial aggregation of landscape elements that would affect the ecological functions and sustenance of natural resources. Land use changes have also altered rainfall-runoff system, which decides the hydrologic regime within a landscape. Hydrological regime refers to the water yield variability [1, 2], and is dependent on the catchment characteristics [3] such as shape, size, topography, land use, time [4, 5]. Catchment hydrology typically focuses on the understanding of the effect of the spatiotemporal distribution of vegetation, soil and topographical properties, soil moisture, the runoff response. Western Ghats being the water tower of peninsular India is the birthplace of $43+$ perennial rivers. The region is endowed worth the exceptional biodiversity (flora and fauna species - endemic and endangered) and is hence being designated as one among the 35 biodiversity hotspots $[6,7$, 8]. Unplanned developmental activities during the postindependence era, has resulted large scale anthropogenic activities including agriculture, horticulture, monoculture, construction dams for irrigation or hydroelectric projects. The implications of these activities are evident from barren hill tops, alteration in the natural flow regimes $[9,10,11,12$, 13], enhanced risk of extremities (floods or droughts), etc. This necessitates an understanding of the hydrological behavior considering complex catchment processes. In the current communication, the study attempts to understand the role of various landscape elements on the hydrological regime through continuous monitoring of streams along Chandiholé, sub catchment Aghanashini river, Uttara Kannada District, Karnataka. 


\section{STUDY AREA}

Chandiholé is a tributary of Aghanashini river originating at Yaana. Four sub catchments with similar meteorological features namely Yaana, Beilangi, Mastihalla and Aanegundi (Chandiholé) as shown in Fig.1 were monitored for hydrological variability between April 2014 to April 2016. Yaana, Beilangi and Mastihalla were the tributaries flowing to Aanegundi. Yaana has a catchment area of 3.36 sq.km,
Beilangi 3.93 sq.km, Mastihalla 5.63 sq.km, Aanegundi 73.62 sq.km. Rainfall in the catchment varies between 4190 $\mathrm{mm}$ to $4850 \mathrm{~mm}$ (Figure 4 ). About $85 \%$ of monsoon is due to the south west monsoon. Forest cover in the catchment ranges from moist deciduous forest towards the valleys to Semi evergreen at the mountain ranges. Yaana catchment having Evergreen forests. Soils in the catchment are Lateritic and Clayey.

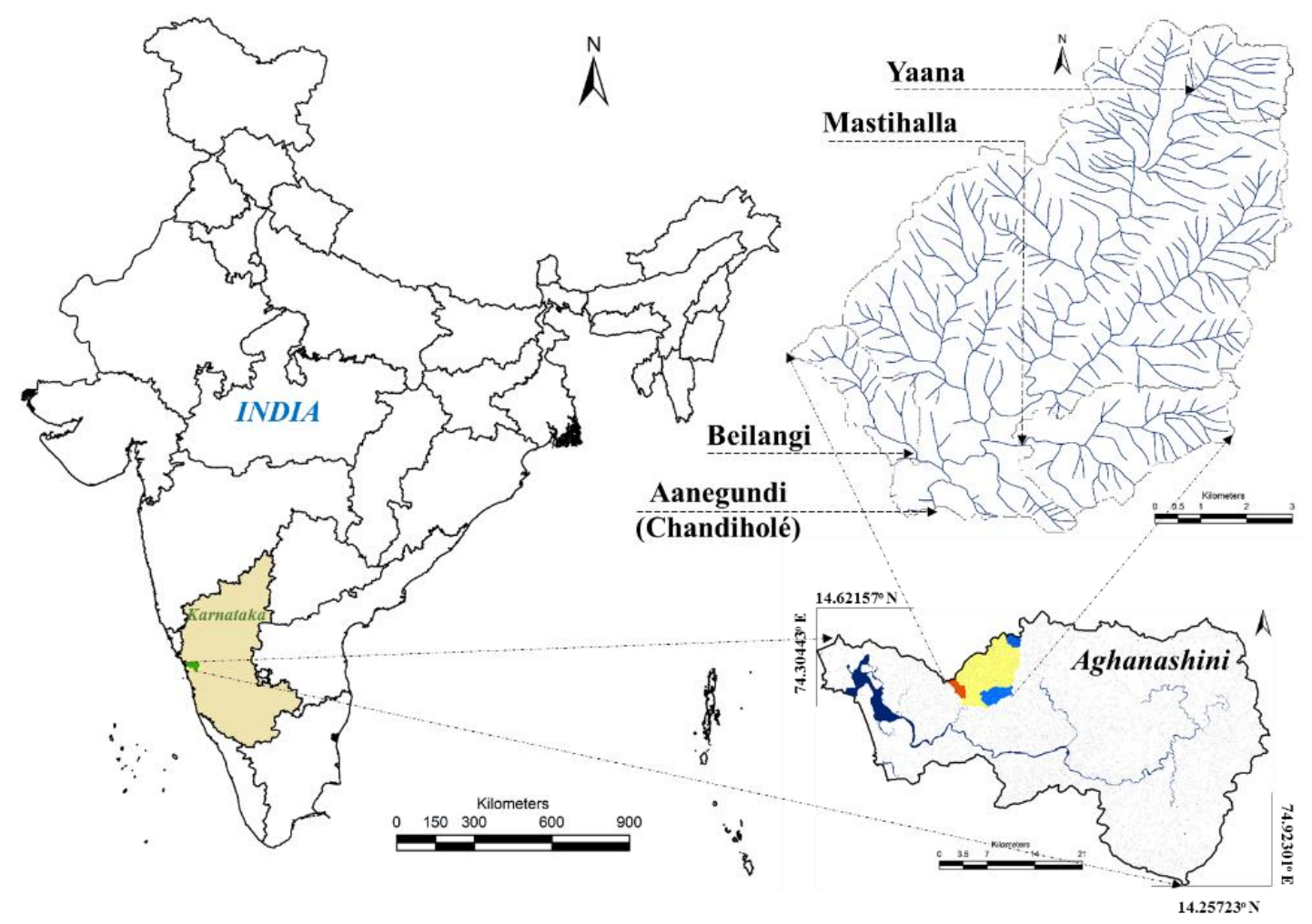

Fig. 1. Study area

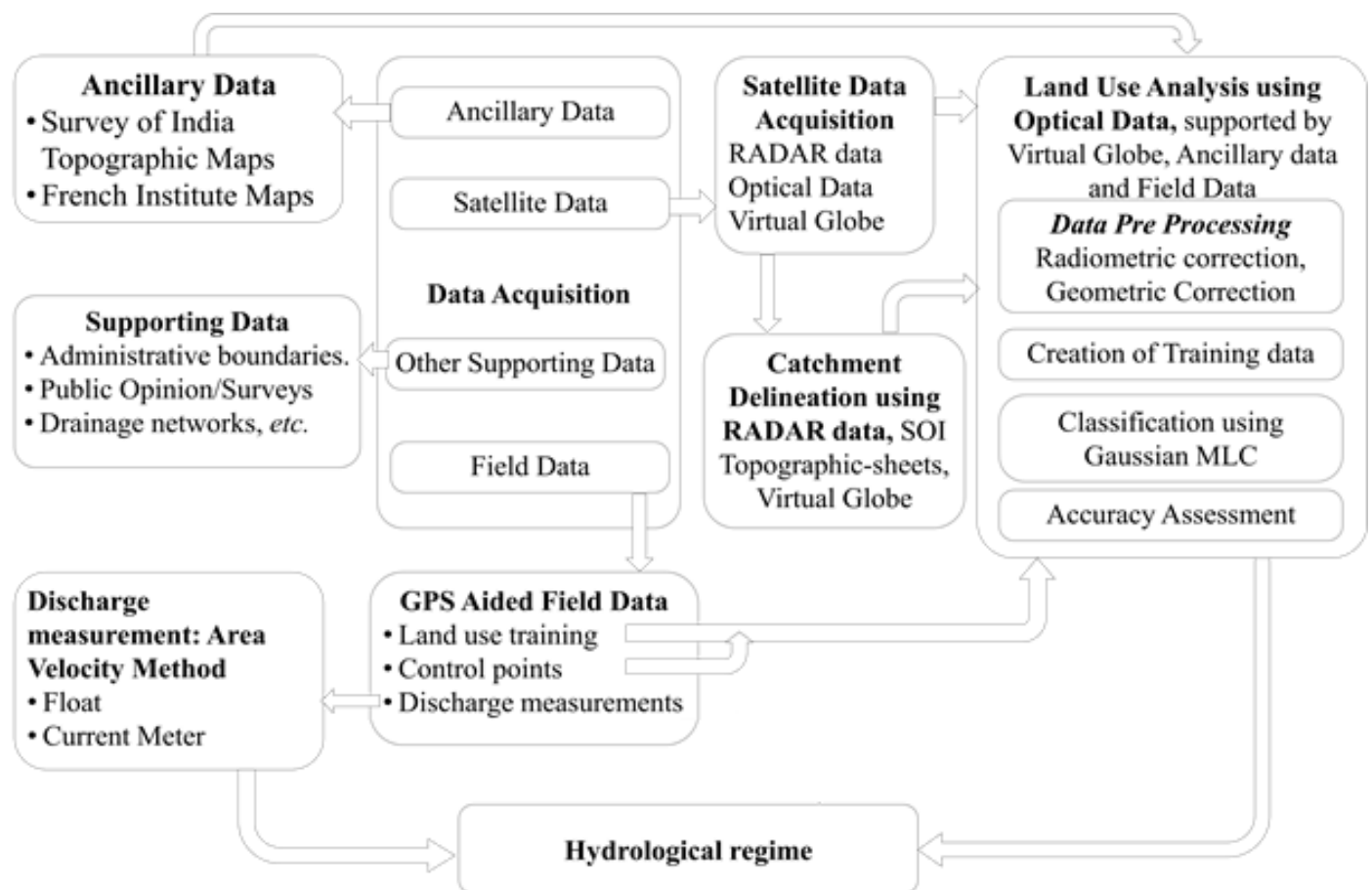

Fig.2.Method involved 

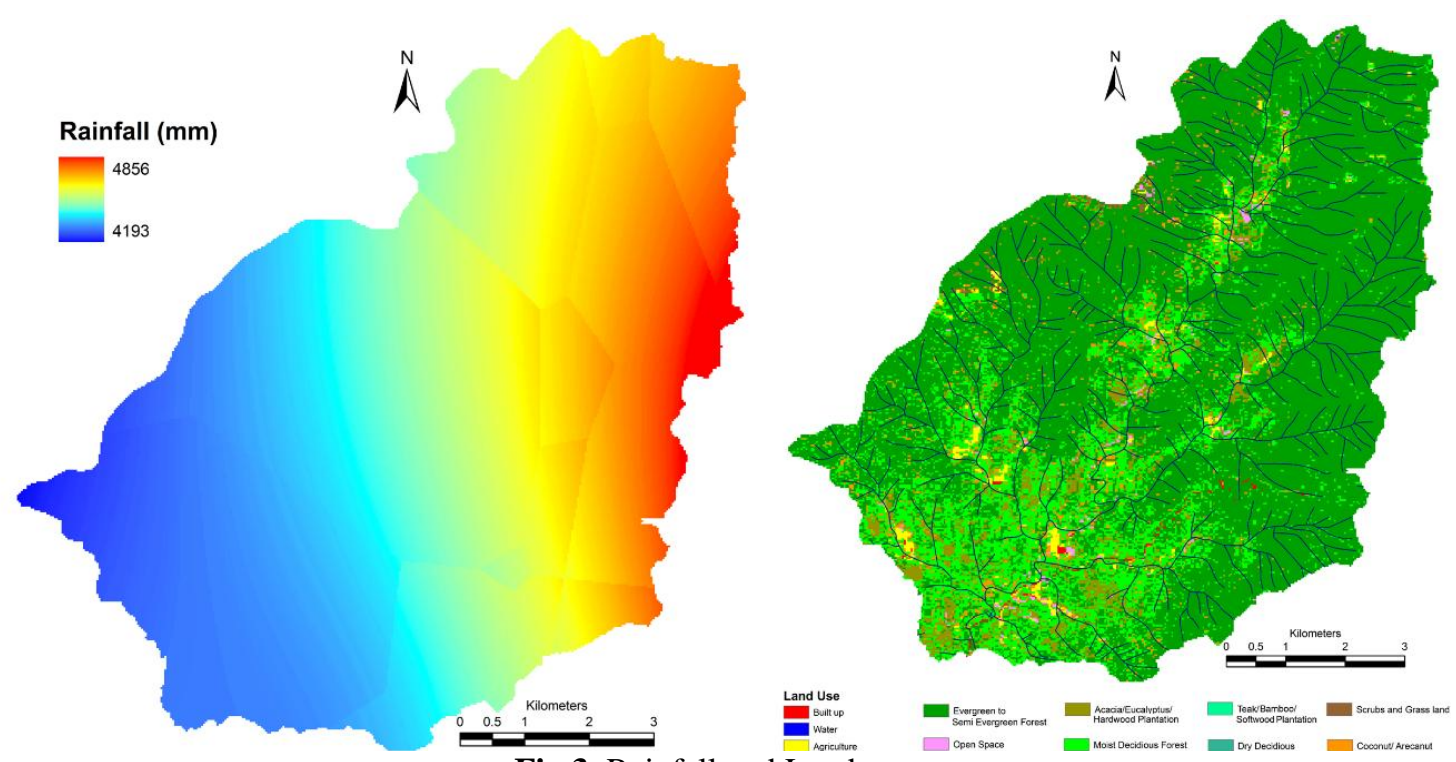

Fig.3. Rainfall and Land use

\section{DATA AND METHOD}

Fig. 2 describes the method involved in understanding the hydrological regime of catchments under carried landscape conditions. The method can be divided into three groups (i) data acquisition, (ii) land use assessment, and (iii) hydrological assessment.

Data acquisition involves collection of (a) remote sensing data such as RADAR data - SRTM 30m [14] for topography assessment, Optical Data - IRSP6 LISS IV [15] for land use analysis, aided with online spatial data portals - Google earth/Bhuvan [16,17]; (b) Collection of ancillary data such as the Survey of India 1:50000 topographic sheets [18] for base layers - extraction of drainage network, identification of administrative divisions, French institute maps [19] for forest type identification; (c) field data collection with precalibrated hand held GPS (Global Positioning System) for collection of (i) training data, (ii) control points for optical satellite data preprocessing and water yield assessment at surface and sub-surfaces. Land use and Hydrological assessment was carried our using standard protocols [21, 22, $23,24,25,26,27]$.

\section{RESULTS AND DISCUSSIONS}

Land use in the Chandiholé catchment is as depicted in Fig.3 and Table 1.The results indicate that the catchments are dominated with forest cover, over $90 \%$. Yaana catchement is dominated by evergreen forests encompassing 95.5\% of the catchment area. Mastihalla and Aanegundi with 71 and $72 \%$ evergreen forest, Beilangi with $46 \%$ evergreen forests.

Hydrological investigations: Field observations carried out at all the four study sites are presented in Fig.4. Discharge measurements were carried out using area velocity method. These catchments are of varied sizes, and hence the discharges were normalized by taking the ratio of discharge and catchment area from cum/s to $\mathrm{mm} /$ day. Hydrological assessment at Mastihalla and Beilangi showed that the streams were intermittent with flows up to 8 months, Water yield in Yaana catchment varied between as low as 0.65 $\mathrm{mm}$ /day during post monsoons and as high as $299 \mathrm{~mm} /$ day in the monsoons. Whereas Aanegindi had highest water yield of $263 \mathrm{~mm} /$ day, during monsoons. Yaana catchment is perennial, while Aanegundi was perennial during 2014 2015 and intermittent during 2015 - 2016, which can be attributed to the control of water with the construction of check dams for irrigation (horticulture purposes). Presence of native evergreen species and less anthropogenic activities in catchment indicated that even during low monsoon years, Yaana had higher water potential during the lean seasons, whereas the other catchments were intermittent with flow upto 7 months ( Beilangi and Mastihalla),about 9 months (Aanegundi).

Table 1: Landuse dynamics in Aghanashini river catchment

\begin{tabular}{|c|c|c|c|c|}
\hline Land use & $\begin{array}{l}\text { Yaa } \\
\text { na }\end{array}$ & $\begin{array}{l}\text { Beilan } \\
\text { gi }\end{array}$ & $\begin{array}{l}\text { Mastiha } \\
\text { lla }\end{array}$ & $\begin{array}{l}\text { Aanegu } \\
\text { ndi }\end{array}$ \\
\hline Built up & $0.0 \%$ & $0.2 \%$ & $0.5 \%$ & $0.2 \%$ \\
\hline Agriculture & $0.4 \%$ & $2.2 \%$ & $0.4 \%$ & $1.1 \%$ \\
\hline Open Spaces & $0.2 \%$ & $0.2 \%$ & $0.2 \%$ & $0.5 \%$ \\
\hline $\begin{array}{l}\text { Moist } \\
\text { Deciduous } \\
\text { Forest }\end{array}$ & $3.0 \%$ & $36.3 \%$ & $21.4 \%$ & $18.7 \%$ \\
\hline $\begin{array}{l}\text { Evergreen } \\
\text { Forest }\end{array}$ & $\begin{array}{l}95.5 \\
\%\end{array}$ & $46.3 \%$ & $71.3 \%$ & $72.2 \%$ \\
\hline $\begin{array}{l}\text { Scrub/Grass } \\
\text { land }\end{array}$ & $0.1 \%$ & $0.0 \%$ & $0.0 \%$ & $0.2 \%$ \\
\hline $\begin{array}{l}\text { Acacia/Eucaly } \\
\text { ptus }\end{array}$ & $0.3 \%$ & $10.9 \%$ & $4.9 \%$ & $4.9 \%$ \\
\hline $\begin{array}{l}\text { Arecanut/ } \\
\text { Coconut }\end{array}$ & $0.5 \%$ & $3.9 \%$ & $1.3 \%$ & $2.1 \%$ \\
\hline
\end{tabular}




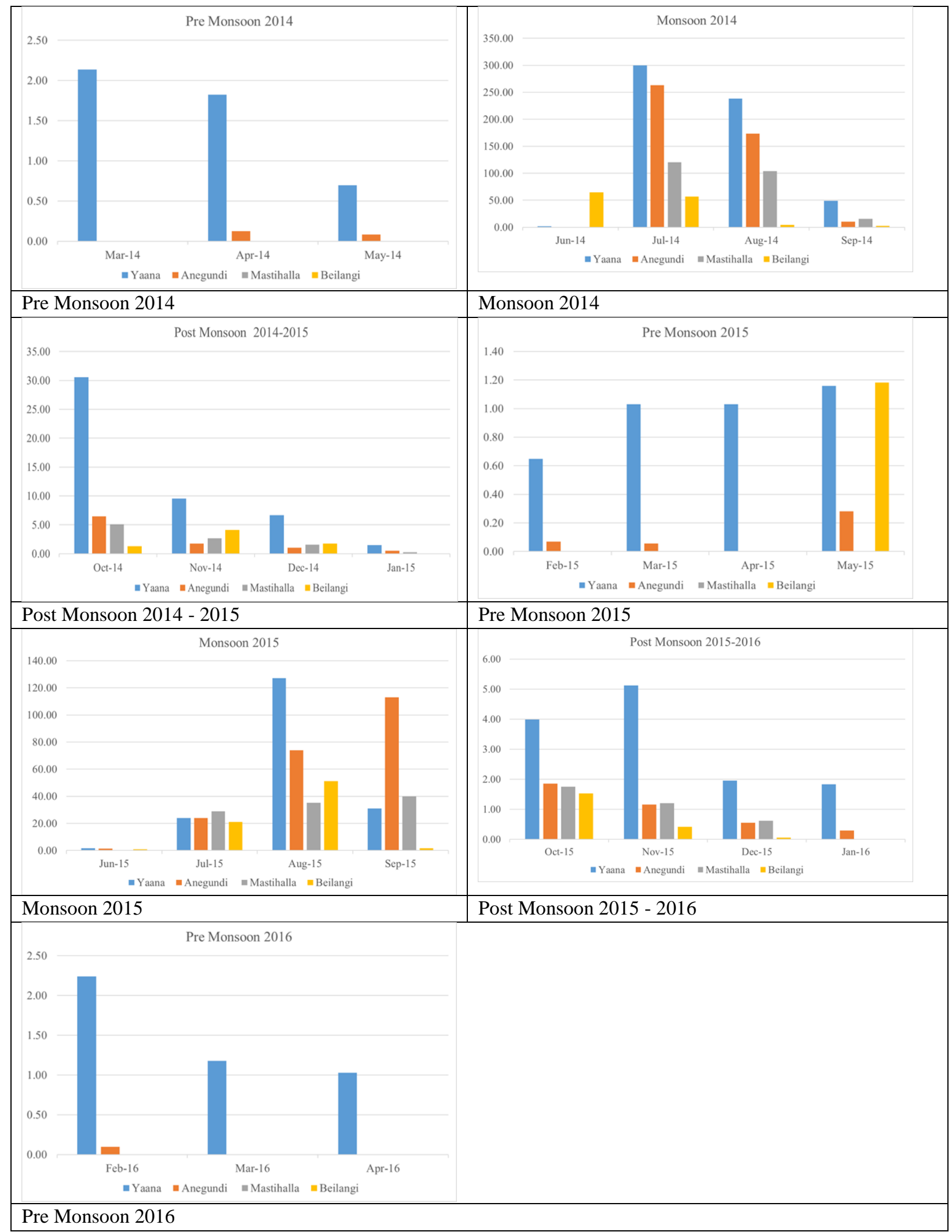

Fig. 4. Field Observations between March 2014 to April 2016 


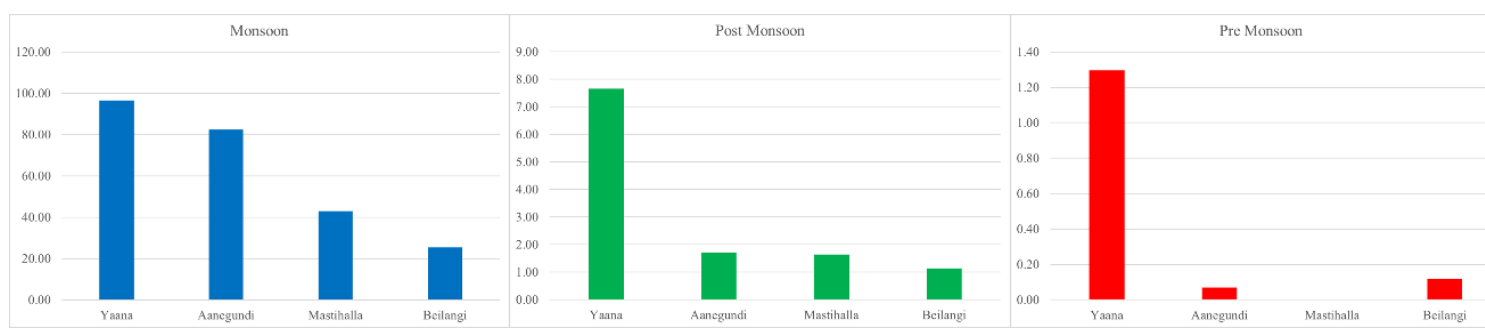

Fig 5. Comparative assessment of Water Yield (average yield across seasons, y-axis: mm/day)

Comparitive assessment (Fig. 5 and Table 2) across the catchments indicated that Yaana is perennial with higher water yield of $7.65 \mathrm{~mm} /$ day and $1.3 \mathrm{~mm} /$ day in post and pre monsoon seasons, Beilangi with $1.14 \mathrm{~mm} /$ day and 0.12 $\mathrm{mm}$ /day. Mastihalla had $1.64 \mathrm{~mm} /$ day during post monsoon, and $0 \mathrm{~mm}$ /day during pre-monsoons across 2014 - 2016. Aanegundi is dependent on all 3 catchments, with major contribution by Yaana stream. Higher the subsurface flows can be attributed to higher infiltration capabilities and water holding capacities of native forests compared to disturbed forests. Even though the forest area is evergreen in Mastihalla and Beilangi catchments, disturbances such as excess removal of leaf litter for horticulture activities, cutting trees for firewood, have reduced the soil moisture and organic matter which play a major role in holding water for longer duration. Anthropogenic activities have enhanced the density of soil resulting in lower infiltration with increased overland flows.

Table 2: Comparative assessment of Water Yield (average yield across seasons, y-axis: $\mathrm{mm} /$ day)

\begin{tabular}{|l|l|l|l|}
\hline Gauging Station & $\begin{array}{l}\text { Pre } \\
\text { Monsoon }\end{array}$ & Monsoon & $\begin{array}{l}\text { Post } \\
\text { Monsoon }\end{array}$ \\
\hline Yaana & 1.3 & 96.54 & 7.65 \\
\hline Aanegundi & 0.07 & 82.39 & 1.7 \\
\hline Mastihalla & 0 & 42.99 & 1.64 \\
\hline Beilangi & 0.12 & 25.31 & 1.14 \\
\hline
\end{tabular}

\section{CONCLUSION}

Hydrological assessment of four catchments having similar meteorological, geological and topgraphic characteristics in Chandihole highlights the role of land cover dynamics and associated anthropogenic activates on the hydrological regime. Undisturbed catchments (such as Yaana catchment)with native vegetation showed presence of perennial streams with rich water storage in the substrata, which flows as either pipe flows or as base flows during the post and pre monsoon seasons. Whereas catchments dominated with anthropogenic activities have higher overland flows during monsoon with reduced water yield during post monsoons and flow of 8 to 10 months. Presence of undisturbed forest shows that the natural flow is maintained which is explained by the presence of rich flora and fauna in the aquatic and terrestrial habitats. The results also highlight higher water yield (5 to 10 folds) in unaltered catchments with native vegetation cover as against the altered or disturbed landscapes during the post and pre monsoon seasons. This study emphasizes on the need for maintaining native vegetation in catchments to ensure sustained water yield..

\section{ACKNOWLEDGMENT}

We are grateful to (i) the Ministry of Environment, Forest and Climate Change, Government of India; (ii) NRDMS division, the Ministry of Science and Technology, Government of India, (iii) Indian Institute of Science for continuous financial and infrastructure support, (iv) People of Uttara Kannada, for all their continuous support during the field investigations, (iv) National Remote Sensing Centre, NRSC for optical data (v) United States Geological Survey, and radar data (SRTM).

\section{REFERENCES}

[1] http://ebooks.narotama.ac.id/files/Hydrology;\%20A\% 20Science $\% 20$ of\%20Nature/Chapter\%2010\%20Hydr ological\%20Regimes.pdf

[2] T.V. Ramachandra, S. Vinay, M. D. S. Chandran, S. Bharath and A.Shashishankar, 2017, Hydrological regime dependence on catchment vegetation dynamics, In proceedings of WIEZ 2017 - IIT Kharagpur, Kolkata, India, January 6 - 7, 2017.

[3] http://echo2.epfl.ch/VICAIRE/mod_1a/chapt_6/main. htm

[4] T. V. Ramachandra, B. Setturu, and M. D. S Chandran, 2016. Geospatial analysis of forest fragmentation in Uttara Kannada District, India. Forest Ecosystems, 3(1), 1-15.

[5] T. V. Ramachandra, M. D. S. Chandran, P. B. Sudarshan, H. A. Bharath, G. R. Rao. and D. M. Vishnu, 2013. Status of Forest in Shimoga District, Karnataka., Sahyadri Conservation Series 23, ENVIS Technical Report: 53, May 2013, Energy \& Wetlands Research Group, Centre for Ecological Sciences, Indian Institute of Science, Bangalore 560012.

[6] Biodiversity a-z, http://biodiversityaz.org/content/biodiversity-hotspots

[7] R. J. Daniels, and V. Jayshree, 2008, "Western GhatsBiodiversity, People, Conservation", Rupa and Co.

[8] Y. Gunnell and B. P. Radhakrishna, 2001, SahyādriThe Great Escarpment of Indian Subcontinent, Patters of Landscape development in Western Ghats, geological Society of India, Memoir 47(1).

[9] T. V. Ramachandra, M. D. S. Chandran, S. Vinay, P. B. Sudarshan, D. M. Vishnu, G.R. Rao, N. Srikanth, Naik., and H. A. Bharath, 2016.Sacred Groves (Kan 
forests) of Sagarataluk, Shimoga district, Sahaydri Conservation Series: 54, ENVIS Technical Report 102, Energy \& Wetlands Research Group, CES, IISc, Bangalore, India.

[10] T. V. Ramachandra, M. D. S Chandran, H. Surya Prakash Shenoy, G. R. Rao, S. Vinay, D. M. Vishnu and N. Srikanth, 2012. Kumaradhara River Basin, Karnataka Western Ghats: Need for Conservation and Sustainable Use., Sahyadri Conservation Series 24, ENVIS Technical Report: 54, April 2013, Energy \& Wetlands Research Group, Centre for Ecological Sciences, Indian Institute of Science, Bangalore 560 012.

[11] The Brisbane Declaration, 10th International River symposium and International Environmental Flows Conference, 2007.

[12] T.V. Ramachandra, S. Vinay, andH. A. Bharath, "Environmental Flow Assessment in a lotic ecosystem of Central Western Ghats, India", Hydrology: Current Research, 7: 248. doi: 10.4172/2157-7587.1000248, 2016.

[13] Vinay, S., Bharath, H. A., Chandran, M. D. S., Shashishankar, A., Ramachandra, T. V., 2016, Linkages between Catchment landscape dynamics and the Natural Flow Regime, International Journal of Earth Sciences and Engineering, 9(3), pp 244 251. ISSN $0974-5904$

[14] United States Geological Survey, http://earthexplorer.usgs.gov/

[15] National Remote Sensing Centre, https://www.nrsc.gov.in/

[16] Google earth, https://earth.google.com/

[17] Bhuvan, www.bhuvan.nrsc.gov.in/

[18] Survey of India, http://www.surveyofindia.gov.in/

[19] French institute maps, www.ifpindia.org/content/map-archives

[20] T.M. Lillesand, and R. W. Kiefer, "Remote Sensing and Image Interpretation", Fourth Edition, John Wiley and Sons, ISBN 9971-51-427-3, 215-216, 2002.

[21] J. R. Jensen, "Introductory Digital Image Processing: A Remote Sensing Perspective", Third Edition, Pearson Series in Geographic Information Science, ISBN13: 9780131453616, 2004.

[22] F. F. Sabins, "Remote Sensing: Principles and Interpretation", Third Edition, Waveland Press, ISBN: 9781577665076, 2007.

[23] T. V. Ramachandra, H. A. Bharath, and D. S. Durgappa, "Insights to Urban Dynamics through Landscape Spatial Pattern Analysis", International Journal of Applied Earth Observation and Geoinformation, 18, pp. 329-343, 2012.

[24] R. O. Duda, P. E. Hart, and D. G. Stork, "Pattern Classification", A Wiley-Interscience Publication, Second Edition, ISBN 9814-12-602-0, 2000.

[25] H. M. Raghunath, "Hydrology", Wiley Eastern Limited, ISBN: 0-85226-746-0, 1985.

[26] K. Subramanya, "Engineering Hydrology", Tata McGraw-Hill publishing company limited, New Delhi, Second Edition. ISBN: 0-07-462449-8, 2005.
[27] S. Vinay, D. M. Vishnu, N. Srikanth, K. S. Asulabha, V.Sincy, G. R. Rao, A.Shashishankar, M. D. S. Chandran, and T. V. Ramachandra,2016, Hydrological regime in Sacred Groves and NonSacred Groves of Central Western Ghats, In proceedings of Lake 2016, Moodbidiri, Dakshina Kannada, Karnataka, India, December 28 - 31, 2016. 